$\sqrt{3}$

J. Bio-Sci. 28: 105-110, 2020

ISSN 1023-8654

http://www.banglajol.info/index.php/JBS/index

DOI: https://doi.org/10.3329/jbs.v28i0.44716

\title{
EFFECTS OF PLANTING METHOD ON YIELD AND YIELD ATTRIBUTING CHARACTERS IN CHICKPEA (CICER ARIETINUM L.)
}

\author{
MS Alam ${ }^{1 *}$, FMA Haydar² and A Hoque ${ }^{1}$ \\ ${ }^{* 1}$ Department of Agronomy and Agricultural Extension, University of Rajshahi, Bangladesh \\ 2Department of Botany, University of Rajshahi, Bangladesh
}

\begin{abstract}
The experiment was conducted to study the effect of planting method on yield and yield attributing characters in chickpea. A randomized complete block design was adopted for the experiment with three replications. Four variety viz. BAU-1, BINA Chola-4, BINA Chola-5 and BINA Chola-9 and two planting method i.e. line sowing and ridge sowing were used in the experiment. The highest seed yield (1.81 ton/ha) was obtained from BINA Chola-4 and the lowest one (1.31 ton/ha) was found in BARI Chola-9. The seed yield was higher in ridge sowing (1.57ton/ha) and the lower (1.53 ton/ha) in line sowing. The highest seed yield (1.83 ton/ha) was obtained from BINA Chola-4 with ridge sowing and the lowest (1.30 ton/ha) was obtained from BARI Chola-9 in line sowing. It is concluded that ridge sowing is better than line sowing for the yield of chickpea.
\end{abstract}

Key words: Chickpea, Planting method, Variety, Yield components and yield

\section{Introduction}

Chickpea (Cicer arietinum L.) is a major pulse crop in Bangladesh standing $5^{\text {th }}$ position in respect of area and production among the pulse crop (BBS 2012). They are rich source of protein and they sustain productivity in cropping system through biological nitrogen fixation process. As the population of our country is increasing day by day, the demand of chickpea is also increasing. Therefore, we need to increase the production of chickpea. It is a well-recognized concept that planting method greatly affects chickpea production. Increased removal of micronutrients as a consequence of the adoption of high yielding varieties and intensive cropping resulting negative effect on yield. The ridge sowing method may give better result than line sowing method for high seed production in chickpea. The raised bed planting of chickpea provided an environment much suitable for the crop growth. Eventually the crop yield under the raised bed planting was higher than that under the flat bed planting. This is well evident from the results of the two years study. Moreover lesser amount of seed was required under the raised bed planting. Pramanik et al. (2009) in their study of raised bed planting with chickpea have also reported that raised bed planting gave higher grain yield than the flat bed planting. Khambalkar et al. (2014) in their study on the performance of bed-furrow planter in winter season of dry land crops have reported that there was an increase in yield of chickpea by $12.5 \%$ using broad bed and furrow system of planting as compared to the traditional flatbed method of sowing.

Pulse crops play an important role in agriculture. Besides being rich in protein, they sustain productivity in cropping system. Their ability to use atmospheric nitrogen through biological nitrogen fixation bacteria is economically more sound and environmentally acceptable. Pulses are considered secondary to cereal crops and grown on marginal soils, as they are perceived to be low yielding and less remunerative crops. As a result, the growth rate of production of pulses in major pulse growing countries in the world is low compared

*Author for correspondence: sami@ru.ac.bd 
to cereals. As a result of ever increasing the population, availability of pulses shown sharp declined. Respective government is therefore forced to import pulses to meet at least a part of growing demand. Hence, there is need to increase the seed yield and quality with particular reference to chickpea. There are many factors responsible for the low yield. The use of traditional or low yielding varieties and adoption of poor management practices are of great importance. Amongst the agronomic practices, sowing methods and varietal performance are of great importance (Reddy et al. 2003). Various genotypes behave differently due to their plant architecture. Under such situation plant variety play an important role in improving the productivity of crop.

Several reasons have been attributed to low productivity of which the major ones are 90 percent of its area is under rainfed condition, besides it is grown as post-monsoon winter crop on conserved soil moisture. Among many reasons, less water availability during its growing period is one of the major factors for low productivity of chickpea. Several workers have reported the positive response of seed yield in chickpea to planting methods under protective irrigated condition. Chickpea seed yield can be increased by providing suitable planting methods (Agarwal et al. 1997). So there is need to adopt a suitable management practices like a proper planting method and to develop high yielding genotypes. Considering the above information the present study was taken to observe the effect of planting method on the seed yield of chickpea.

\section{Materials and Methods}

The present research work was carried out at the Agronomy Field, Department of Agronomy and Agricultural Extension, University of Rajshahi during the period from November 2016 to April 2017. The experiment was carried out in randomized complete block design three replications. Four variety viz. BAU-1, BINA Chola-4, BARI Chola-5, BARI Chola-9 and two planting method i.e. line sowing and ridge sowing were used in the experiment. The experiment was laid out in randomized complete block design with three replications. Variety was allocated in the main plot, planting method in the sub-plot. Different intercultural operations were done as and when necessary. The data on plant height $(\mathrm{cm})$, number of branches/plant, total pods/plant, effective pods/plant, non-effective pods/plant, 1000 seed weight, seed yield (ton/ha), straw yield (ton/ha), and biological yield (ton/ha) were recorded. The data were analyzed statistically using the analysis of variance (ANOVA) and the mean differences among the treatments were adjudged by Duncan's Multiple Range Test with the help of MSTAT-C software.

\section{Results and Discussion}

\section{Plant height}

Variety of chickpea responded significantly on plant height. BINA Chola-4 produced the tallest $(58.956 \mathrm{~cm})$ plant and BARI Chola-9 gave the shortest $(52.601 \mathrm{~cm})$ one. Similar results were also observed by lqbal et al. (2001) and Khan et al. (2000).Plant height varied significantly due to planting method (Table 1). The tallest plant $(56.60 \mathrm{~cm})$ as recorded in ridge sowing method and shortest one $(55.42 \mathrm{~cm})$ was recorded in line sowing (Table 1). In ridge sowing method generally provide better atmospheric condition (e.g high moisture content) than line sowing. The interaction effect of variety and planting method on plant height was statistically significant (Table 2). It was observed that highest plant height $(60.01 \mathrm{~cm})$ was obtained in BINA Chola-4 with ridge sowing and the shortest one $(52.13 \mathrm{~cm})$ was recorded from BARI Chola-9 with line sowing.

\section{Branches per plant}

Branches of plant varied significantly due to varieties. The highest number of branches per plant (19.56) was obtained from BINA Chola-4 and the lowest number of branches/plant (11.19) was obtained from BARI Chola-9. This result is quite similar to Rashid et al. (1999). Branches/plant was influenced significantly by the 
planting method (Table 1). The highest number of branches/plant (15.27) obtained in ridge sowing and the lowest number (13.83) was recorded from line sowing (Table 1). Ridge sowing method facilitated the crop with high depth of root, as a result nutrient uptake was high. Similar result was reported by Pramanik et al. (2009).The interaction effect of variety and planting method on branches per plant was not statistically significant. Apparently the higher number of branches/plant was obtained from BINA Chola-4 with ridge sowing and the lowest one in BARI Chola-9 variety with line sowing (Table 2).

\section{Total pod per plant}

Variety showed a significant variation in total pods/plant. The higher pods/plant (59.66) was produced by variety BINA Chola-4. The lower pods/plant (34.94) was produced by variety BARI Chola-9. Plating method was statistically significant on the number of total pods/plant. The ridge sowing method gave the higher number of pods/plant (48.63) and lower was (46.02) observed in line sowing method (Table 1). Similar results were shown by Dharmaraj et al. (2005).Total pods/plant was not significant due to the interaction of variety and planting method. The highest value (61.67) was obtained in BINA Chola-4 with ridge sowing and the lowest one (33.67) in BARI Chola-9 with line sowing (Table 2).

Table 1. Effect of variety and planting method on yield and yield components of chickpea

\begin{tabular}{|c|c|c|c|c|c|c|c|c|c|}
\hline 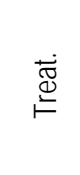 & 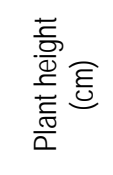 & 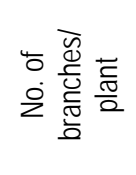 & $\frac{\overline{8}}{\frac{8}{2}} \frac{\pi}{\frac{\pi}{0}}$ & 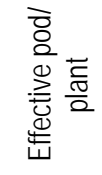 & 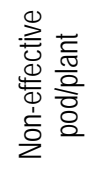 & 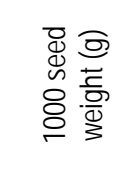 & 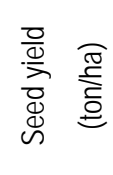 & 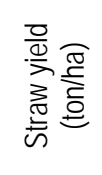 & $\begin{array}{l}\text { 정 } \\
\text { 응 } \\
\text { 응 } \\
\text { 음 응 }\end{array}$ \\
\hline \multicolumn{10}{|c|}{ Variety } \\
\hline$V_{1}$ & $57.20 \mathrm{~b}$ & $15.04 b$ & $48.44 b$ & $40.00 \mathrm{~b}$ & $8.44 \mathrm{c}$ & $135.11 b$ & $1.57 \mathrm{~b}$ & $2.05 b$ & $3.63 b$ \\
\hline$V_{2}$ & $58.95 a$ & $19.56 a$ & $59.66 \mathrm{a}$ & $51.33 a$ & $8.33 d$ & $142.02 \mathrm{a}$ & $1.81 \mathrm{a}$ & $2.32 \mathrm{a}$ & 4.13a \\
\hline$V_{3}$ & $55.30 \mathrm{c}$ & $12.41 \mathrm{c}$ & $45.83 \mathrm{c}$ & $36.55 \mathrm{c}$ & $9.22 \mathrm{~b}$ & $121.73 c$ & $1.50 \mathrm{c}$ & $1.95 c$ & $3.45 c$ \\
\hline $\mathrm{V}_{4}$ & $52.60 d$ & $11.19 d$ & $34.94 d$ & $25.16 \mathrm{~d}$ & $9.77 a$ & $125.50 d$ & $1.31 d$ & $1.71 d$ & $3.03 d$ \\
\hline LS & 0.05 & 0.01 & 0.05 & 0.05 & 0.05 & 0.05 & 0.01 & 0.01 & 0.01 \\
\hline CV\% & 3.39 & 6.77 & 7.06 & 5.85 & 16.72 & 11.18 & 2.27 & 2.76 & 2.27 \\
\hline \multicolumn{10}{|c|}{ Planting method } \\
\hline $\mathrm{S}_{1}$ & $55.42 b$ & $13.83 b$ & $46.02 \mathrm{~b}$ & $36.79 b$ & 8.72 & 132.11 & $1.53 b$ & $1.99 b$ & $3.52 b$ \\
\hline $\mathrm{S}_{2}$ & $56.60 \mathrm{a}$ & $15.27 a$ & $48.63 a$ & $39.89 a$ & 9.16 & 130.07 & $1.57 a$ & $2.03 a$ & $3.60 \mathrm{a}$ \\
\hline LS & 0.01 & 0.01 & 0.05 & 0.05 & - & - & 0.05 & 0.01 & 0.01 \\
\hline CV\% & 3.39 & 6.77 & 7.06 & 5.85 & 16.72 & 11.18 & 2.27 & 2.76 & 2.27 \\
\hline
\end{tabular}

In a column figures having similar letters (S) or without letters (s) do not differ significantly as per DMRT. $V_{1}=$ BAU-1, $V_{2}=$ BINA Chola-4' $V_{3}=$ BARI Chola-5, $V_{4}=$ BARI Chola-9, S $_{1}=$ Line sowing, $S_{2}=$ Ridge sowing, LS = Level of significance, $C V=$ Co-efficient of variation, - = Non-significant. 


\section{Effective pods per plant}

Effective pods/plant showed a significant response due to varieties (Table 1). The highest number (51.33) of effective pod/plant was obtained from BINA Chola-4. BARI Chola-9 showed the lowest number (25.16) of effective pods/plant. Karim (2004) observed similar result and reported that the number of effective pods/plant showed significant response to varieties. Number of effective pods/plant was significantly influenced by planting method (Table 1). The highest number of effective pods/plant (39.89) was recorded in ridge sowing method and the lowest one (36.79) was found in line sowing method (Table 1). This result was supported by Dutta et al. (1998). The interaction between variety and planting method on the production of effective pod/plant was not significant (Table 2). The highest effective pods/plant was obtained from the variety BINA Chola- 4 with ridge sowing method and the lowest one from variety BARI Chola-9 with line lowing method.

\section{Non effective pods per plant}

Variety showed a significant effect in number of non-effective pods/plant (Table1). The highest number of non-effective pods/plant (9.77) was produced by variety BARI Chola-9 and lowest non-effective pods/plant (8.33) was produced by variety BINA Chola-4.The number of non-effective pods/plant was not influenced significantly by planting method (Table 1). The highest number of non-effective pods/plant (9.16) was obtained from ridge sowing method and the lowest one (8.72) in line sowing method. The interaction effect of variety and planting method on the number of non-effective pods/plant was not significant (Table 2). But numerically the highest value (9.81) was obtained from variety BINA Chola-4 with ridge sowing method and the lowest value (7.88) in BARI Chola-9 with line sowing method (Table 2).

\section{0 seed weight}

Varietal effect differed significantly in respect to 1000 seed weight (Table1). BINA Chola-4 gave the highest 1000 seed weight $(142.02 \mathrm{~g})$. The lowest 1000 seed weight $(125.5 \mathrm{~g})$ was produced by BARI Chola-9. Thousand seed weight influenced significantly by planting method (Table 2). Table 1 indicates that the highest weight of 1000 seed (132.07 g) was produced in ridge sowing method and the lowest was recorded from $(130.11 \mathrm{~g})$ line sowing method. The 1000 seed weight was significantly influenced by the interaction of variety and planting method (Table 2). Table 2 represents that the BINA Chola-4 resulted highest value of 1000-seed weight $(143.11 \mathrm{~g})$ when it was interacted with the ridge sowing method i.e. $V_{2} \times S_{2}$ combination and the lowest value $(125.35 \mathrm{~g})$ of 1000 seed weight was produced by BARI Chola-9 with line sowing.

\section{Seed yield}

All the varieties differed significantly in respect to seed yield (Table 1). The highest seed yield (1.81 ton/ha) was recorded from the variety BINA Chola-4 due to increased number of effective pods/plant. The lowest seed yield (1.31 ton/ha) was obtained from BARI Chola-9. The significant reduction in yield of BARI Chola-9 was mainly due to the significant reduction in yield components like pods/ plant, seed weight/plant as compared to yield components of BINA Chola-4. Khalid et al. (2001) also observed same results in chickpea. These results are also in concurrence with those of Kumar et al. (2003).

Planting method showed a significant variation in seed yield (Table 1). Table 1 indicates that ridge sowing method gave the highest seed yield (1.57 ton/ha). The lowest grain yield (1.53 ton/ha) was obtained from line sowing method. This result is similar to Dutta et al. (1998). The raised bed planting of chickpea provided an environment much suitable for the crop growth. Joshi and Shrivastava (2017) in their study on modification and performance evaluation of tractor drawn raised bed seed drill under vertisol have reported that the average yield of chickpea by raised bed sowing was $1211.3 \mathrm{~kg} / \mathrm{ha}$ as compared to that viz. 1127.83 
$\mathrm{kg} / \mathrm{ha}$ under conventional practice. Thus here also the raised bed sowing outperformed the conventional of sowing of chickpea. The interaction effect between variety and planting method on seed yield was statistically non-significant (Table 2). The highest yield was recorded from BINA Chola-4 when it was interacted with ridge sowing method and the lowest seed yield was obtained from BARI Chola-9 with line sowing method.

\section{Straw yield}

The effect of variety on straw yield was statistically significant (Table 1). BINA Chola-4 produced the highest straw yield $(2.32$ ton/ha). The lowest straw yield $(1.71$ ton/ha) was produced by BARI Chola-9. Planting method showed a significance variation in straw yield (Table 1). The ridge sowing method gave the highest straw yield (2.03) and the lowest was observed in line sowing method (1.99).The interaction effect between variety and planting method on straw yield was not significant (Table 2). Numerically the highest result was obtained from variety BINA Chola-4 when it was interacted with ridge sowing method.

\section{Biological yield}

The effect of variety on biological yield was statistically significant (Table 1). BINA Chola-4 produced the highest biological yield (4.137 ton/ha). BARI Chola-9 produced the lowest biological yield (3.03 ton/ha). Planting method showed a significant variation in biological yield. Table 1 represents that the ridge sowing method gave the highest biological yield ( 3.60 ton/ha) and the lowest was observed in line sowing method (3.52 ton/ha). This result is similar to Dharmaraj et al. (2005).The interaction effect of variety and planting method on biological yield was statistically significant (Table 2). Data indicates that the highest biological yield was recorded (4.18t ton/ha) in $\mathrm{V}_{2} \mathrm{~S}_{2}$ (BINA Chola-4 with ridge sowing method) and the lowest value was observed in $\mathrm{V}_{4} \mathrm{~S}_{1}$ (BARI Chola-9 with line sowing.

Table 2. Interaction effect of variety and planting method on yield and yield components of chickpea

\begin{tabular}{|c|c|c|c|c|c|c|c|c|c|}
\hline 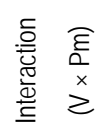 & 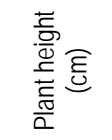 & 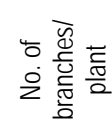 & 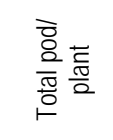 & 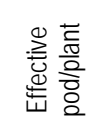 & 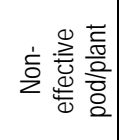 & 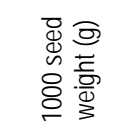 & 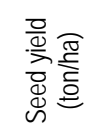 & 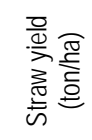 & 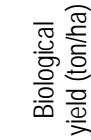 \\
\hline $\mathrm{V}_{1} \mathrm{~S}_{1}$ & $56.80 \mathrm{~d}$ & 14.57 & $46.44 d$ & 38.11 & 8.33 & $133.61 \mathrm{~d}$ & 1.55 & 2.03 & $3.58 \mathrm{~d}$ \\
\hline $\mathrm{V}_{1} \mathrm{~S}_{2}$ & $57.61 \mathrm{~cd}$ & 15.50 & $49.33 \mathrm{~cd}$ & 41.88 & 8.55 & $136.60 \mathrm{~cd}$ & 1.59 & 2.07 & $3.67 \mathrm{~cd}$ \\
\hline $\mathrm{V}_{2} \mathrm{~S}_{1}$ & $57.89 \mathrm{~b}$ & 18.75 & $57.66 \mathrm{~b}$ & 49.77 & 7.88 & $140.87 \mathrm{~b}$ & 1.78 & 2.30 & $4.08 \mathrm{~b}$ \\
\hline $\mathrm{V}_{2} \mathrm{~S}_{2}$ & $60.01 \mathrm{a}$ & 20.38 & $61.66 \mathrm{a}$ & 52.88 & 8.77 & $143.11 \mathrm{a}$ & 1.83 & 2.33 & $4.18 a$ \\
\hline $\mathrm{V}_{3} \mathrm{~S}_{1}$ & 54.87ef & 11.68 & 46.33ef & 35.00 & 9.11 & $114.84 \mathrm{ef}$ & 1.52 & 1.97 & 3.49ef \\
\hline $\mathrm{V}_{3} \mathrm{~S}_{2}$ & 55.73de & 13.13 & 47.33de & 38.11 & 9.33 & $114.84 \mathrm{de}$ & 1.52 & 1.97 & $3.49 \mathrm{de}$ \\
\hline $\mathrm{V}_{4} \mathrm{~S}_{1}$ & 52.13gh & 10.32 & $33.66 \mathrm{gh}$ & 24.22 & 9.55 & $125.35 \mathrm{gh}$ & 1.30 & 1.70 & $3.00 \mathrm{gh}$ \\
\hline $\mathrm{V}_{4} \mathrm{~S}_{2}$ & $53.07 \mathrm{fg}$ & 12.06 & $36.22 \mathrm{fg}$ & 26.23 & 9.81 & $125.65 \mathrm{fg}$ & 1.32 & 1.73 & $3.07 \mathrm{fg}$ \\
\hline LS & 0.05 & NS & 0.05 & NS & NS & 0.05 & NS & NS & 0.05 \\
\hline CV\% & 3.39 & 6.77 & 7.06 & 5.85 & 16.72 & 11.18 & 2.27 & 2.76 & 2.27 \\
\hline
\end{tabular}

In a column figures having similar letters (S) or without letters (s) do not differ significantly as per DMRT. 


\section{Conclusion}

All the yield components and yield varied significantly among the varieties. The highest seed yield (1.81 ton/ha) was obtained from BINA-4 and lowest (1.31 ton/ha) was found from BARI-9 variety. The seed yield was higher in ridge sowing (1.57 ton/ha) and the lowest one (1.53 ton/ha) in line sowing method. From the interaction effect between variety and planting method the highest seed yield (1.83 ton/ha) was obtained from BINA Chola-4 with ridge sowing and lowest (1.30 ton/ha) was found from BARI Chola-9 with line sowing method. It was observed planting has a significant effect on yield of chickpea. It may be concluded that ridge sowing is better than line sowing for maximum yield of chickpea.

\section{References}

Agarwal WC, Dhandiwaal AS, Prabakar A and Auja MS (1997). All India coordinated project for research on water management. Directorate of Water Management Research (ICAR) Patna. pp.138.

BBS (2012). Statistical Yearbook of Bangladesh. Bangladesh Bureau of Statistics, Ministry of Planning, Government of the People's Republic of Bangladesh.

Dharmaraj PS, Lohitaswa HC and Mannur DM (2005). Kar. J. Agric. Sci.18(4): 1087-1089.

Dutta RK, Mia MAB, Lahiri BP, Uddin MM (1998). Growth and yield of lentil in relation to population pressure. Lens News Letter, 25(11): 27-29.

Iqbal HF, Tahir A, Khalid MN, Haq I and Ahmad AN (2001). Response of chickpea growth towards foliar application of gibberellic acid at different growth stages. Pakistan J. Biol. Sci., 4(4): 433-434.

Joshi J and Shrivastava AK (2017). Modification and performance evaluation of tractor drawn raised bed seed drill under vertisol. International Journal of Agricultural Science and Research, 7(3): 385-394.

Khambalkar VP, Waghmare NN, Gajakos AV, Karale DS and Kankal US (2014). Performance of broad bed planter in winter season of dryland crops. International Agricultural Engineering Journal, 23(01): 14-22.

Khan MJ, Khattak RA and Khan MA (2000). Influence of sowing methods on the productivity of canola grown in saline field. Pak. J. Biol. Sci., 3(4): 687-691.

Khalid MR, Qureshi AS and Hossain SA (2001). Biological effect of gamma irradiation and its modulation with gibberellic acid in M1 generation in chickpea (Cicer arietinum L.). Pakistan J. Biol. Sci., 3: 993-995.

Karim MF and Fattah QA (2004). Yield attributes and yield response of chickpea to nitrogen levels and $\mathrm{K}, \mathrm{Na}$, and $\mathrm{P}$ concentrations. Bangladesh J. Life Sci., 16(1): 147-152.

Kumar M, Singh RC, Kumar R and Singh S (2003). Effect of date of sowing and row spacing on performance of chickpea genotype. Haryana J. Agron., 19(2): 140-141.

Pramanik SC, Singh NB and Singh KK (2009). Yield, economics and water use efficiency of chickpea (Cicer arietenum) under various irrigation regimes on raised bed planting system. Indian Journal of Agronomy, 54(3): 315-318.

Rahsid MM, Wahhab MA, Amin MS, Quayyum MA and Alam MS (1999). In: Hand Book on Agro-Technology, Krishi Projukti Hatboi (Eds.), Bangladesh Agricultural Research Institute, Gazipur, Bangladesh. pp. 75-85.

Reddy BVS, Reddy PS, Bidinger F and Blummel M (2003). Crop management factors influencing- yield and quality of crop residues. Field Crops Res., 84: 57-77.

(Manuscript received on July 19, 2019 and revised on November 26, 2019) 